12. McDonagh A. F.: Phototherapy: a new twist to bilirubin. J. Pediatr., 99: 909 (1981).

13. McDonagh, A. F., Palma, L. A., and Lightner, D. A.: Blue light and bilirubin excretion. Science, 208: 145 (1980).

14. Rubaltelli, F. F. and Carli, M.: The effect of light on cutaneous bilirubin. Biol. Neonate, 18: 457 (1971).

15. Sisson, T. R. C., Kendall, N., Shaw, E., and Kechavarz-Oliai, L.: Phototherapy of jaundice in the newborn infant: 11 Effect of various light intensities. J. Pediatr. 81: 35 (1972).

16. Vogl, T. P.: Phototherapy of neonatal hyperbilirubinemia. Bilirubin in unexposed areas of the skin. J. Pediatr., 85: 707 (1974).

17. White, D.: Hardar, G. A., and Reinhold, J. G.: Spectrophotometric measure- ments of bilirubin concentrations in the serum of the newborn by the use of a microcapillary method. Clin. Chem., 4: 211 (1958).

18. Wiese G. and Ballowitz. L.: Phototherapy in Gunn rats 1 I. Further calculations on the effectivity of different irradiances. Biol. Neonate, 39: 113 (1981).

19. Yamanouchi, I., Yamauchi, Y., and Igarashi, I.: Transcutaneous bilirubinometry: Preliminary studies of noninvasive transcutaneous bilirubin meter in Okayama National Hospital. Pediatrics, 65: 195 (1980).

20. Requests for reprints should be addressed to: Dr. Thomas Hegyi, Director, Division of Neonatal Medicine, UMDNJ-Rutgers Medical School, St. Peter's Medical Center, 254 Eastern Ave., New Brunswick, NJ 08903.

21. Received for publication October 6, 1982 .

22. Accepted for publication April 6, 1983.

\title{
Energy Balance and Nitrogen Balance in Growing Low Birthweight Infants Fed Human Milk or Formula
}

\author{
R. K. WHYTE ${ }^{(40.41)}$ R. HASLAM, C. VLAINIC, S. SHANNON, K. SAMULSKI, D. CAMPBELL, \\ H. S. BAYLEY, AND J. C. SINCLAIR \\ Department of Pediatrics, McMaster University, Hamilton, Ontario and Department of Nutrition, University of \\ Guelph, Guelph, Ontario, Canada
}

\section{Summary}

Energy and nitrogen balances were measured in growing low birthweight infants fed either mother's expressed breast milk or a $20 \mathrm{kcal}$ per ounce formula to determine whether or not there were differences between the two dietary groups in (1) the partition of energy among excretion, expenditure, and storage and (2) the relation of energy storage and nitrogen retention to weight gain.

There were no significant differences between the human milk fed infants and formula fed infants in gross energy intake, metabolizable energy intake, nitrogen intake, or nitrogen retention. Energy expenditure was significantly lower in the human milk fed infants than in formula fed infants $(221 \mathrm{~kJ} /(\mathrm{kg}$. day) and 244 $\mathrm{kJ} /(\mathrm{kg}$. day), respectively). There was no difference in mean energy storage between the two groups.

Although weight gains were similar in both dietary groups, the ratio of energy storage to weight gain was significantly greater in infants fed with human milk $(15.3 \mathrm{~kJ} / \mathrm{g}$, S.D. 2.0) than in infants fed formula $(13.2 \mathrm{~kJ} / \mathrm{g}$ S.D. 1.8). There was no significant difference between the two groups in the ratio of nitrogen stored to weight gain.

Estimates of the body composition of the growing fetus (38) have been used as guidelines from which the nutrient requirements of the growing low birthweight infant have been calculated (15). This approach has been challenged (21): the low birthweight infant in an extrauterine environment, with physiologic and environmental conditions differing from those of the fetus, may have different nutrient requirements both for maintenance and for storage in growing tissues. The observation that human milk expressed from preterm mothers differs from that of term mothers $(1,2,3,17)$ has contributed to a renewed interest in the suitability of this food for growing low birthweight infants. Pre- vious studies $(8,28)$ have measured energy balance in growing low birthweight infants fed formula. In this study we have measured both energy and nitrogen balances in growing low birthweight infants fed either their own mother's expressed milk or formula.

The aims of the study are to compare the two dietary groups with regard to $(I)$ the partition of energy intake into energy excretion, expenditure, and storage; $(2)$ the partition of nitrogen intake into excretion and retention; and (3) the relation of energy storage and nitrogen retention to weight gain. From these measurements, the composition of weight gain was estimated for each dietary group.

\section{SUBJECTS AND METHODS}

Informed consent was sought from the parents of healthy, growing, low birthweight infants born at or referred to McMaster University Medical Centre between June 1978 and August 1980. To qualify for the study, each baby had to be receiving all feeds by gavage, free of respiratory or gastrointestinal disease, less than $1800 \mathrm{~g}$ at birth and growing at a rate of at least $10 \mathrm{~g} /(\mathrm{kg}$. day).

Allocation was by maternal preference into a human milk fed group and a formula fed group. Formula (Similac, Ross Laboratories) was obtained after reconstitition and resterilization from a distribution service. Only those infants who were fed exclusively either with formula or with their own mother's expressed milk were included in the study.

Each study consisted of a 14-day balance period during which time the amount of feed intake was measured daily (Fig. 1). Pooled samples of feed and of excreta were collected for analysis during collection periods which comprised the first 3 and the last 3 days of the balance period. Energy expenditure was measured three times, at weekly intervals, on each occasion throughout two interfeed periods ( 4 or $6 \mathrm{~h}$ ). Behavioural state, observed 


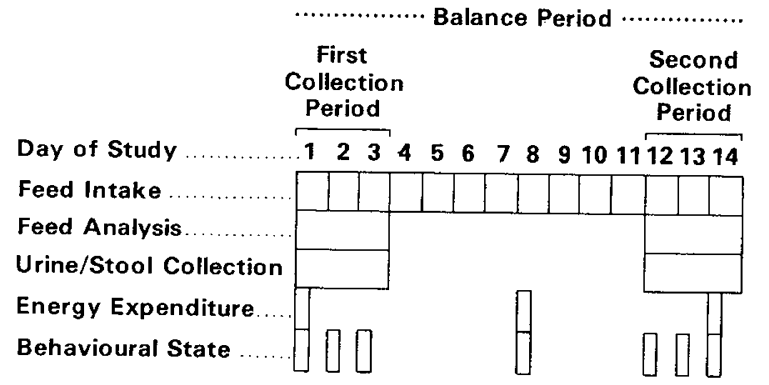

Fig. 1. Organization of balance study.

continuously throughout two interfeed periods, was measured concurrently with energy expenditure and on 4 additional days.

All babies were nursed in a servocontrolled incubator with the skin temperature set at $36.5^{\circ} \mathrm{C}$.

Energy and nitrogen intake. Each baby was fed two or three hourly in amounts depending upon clinical assessment of the infant's tolerance to a goal of $180 \mathrm{ml} /(\mathrm{kg}$. day). The day's allocation of milk or formula was divided equally into containers. These were then weighed before and after feeding. An adjustment was made for the small amounts of feed left in the tubing of the gavage apparatus. The formula was shaken vigorously before feeding and sampled for analysis. Human milk was expressed by mothers, pooled in complete daily collections and refrigerated at $4^{\circ} \mathrm{C}$. Each day's milk was mixed in a domestic blender, divided up immediately into individual feeds, and sampled for analysis. The feed containers were shaken again before giving the whole contents by gavage. All babies received supplements of vitamins [0.3 ml Polyvisol (Mead Johnson) and vitamin D 400 I.U.] daily. Six human milk fed and eleven formula fed infants received supplements of 25 I.U. vitamin E, and seven human milk fed and 17 formula fed infants received calcium supplements $(200$ $400 \mathrm{mg}$ calcium gluconate daily). The experimentally determined energy contents of the supplements were included in the estimates of intake.

Energy and nitrogen excretion. Stool and urine were collected separately using a polyethylene stool collection bag (30) and a metabolic frame (18). The excreta were pooled over each 3-day collection period and frozen for analysis.

Analysis of feed and excreta. The samples of stood were thawed, quantitatively transferred, and freeze-dried. The dried stool was weighed, ground, and mixed for analysis. The total weight of urine was recorded for the 3-day period, and duplicate aliquots of $10 \mathrm{~g}$ were weighed into plastic bags of known weight and gross energy value. The urine was freeze-dried in the bags and then the bag along with the dried urine was combusted in an oxygen bomb calorimeter (Parr Corp., Moline, IL). The gross energy contents of the milk and formula were determined in the same way as the urine. Nitrogen in the stool, urine, milk, and formula was determined by the Kjeldahl procedure (19), the fat content of stool by the Van de Kamer procedure (35), and of the milk by the Bligh and Dyer procedure (6).

Energy expenditure. A Kipp diaferometer was used for the measurement of energy expenditure. This was calibrated with human expired air using a modification of the method described by Ten Hoor (34). At a rate of oxygen consumption or of carbon dioxide production of $6.00 \mathrm{ml} / \mathrm{min}$, the standard deviation of a single value was $0.36 \mathrm{ml} / \mathrm{min}$. The full range over which the diaferometer was calibrated was equivalent to oxygen consumption rates of $0-12 \mathrm{ml} / \mathrm{min}$.

Persistently high respiratory quotients were recorded during the study. These were found to be caused by breath hydrogen, which interfered with the diaferometer and led to an underestimation of the true rate of oxygen consumption. The degree of underestimation depended upon the rate of production of breath hydrogen by the infant. The carbon dioxide recording was not significantly affected; therefore, the mean of minute by minute $\mathrm{VCO}_{2}$ readings taken over the measuring period was used to determine energy expenditure. As the energy equivalent of carbon dioxide depends upon the respiratory quotient, we derived nonprotein respiratory quotients from food quotients (13) estimated from our knowledge of daily metabolizable energy intake, nitrogen and fat intakes and excretions, and carbon dioxide production (see "Appendix"). The energy equivalents of carbon dioxide at various nonprotein respiratory quotients were obtained from tables of Lusk adapted by Brody (7). The values for oxygen consumption were adjusted using the nonprotein respiratory quotients derived as described above.

The diaferometer is an open flow system, and measurements were taken with the infant's head in a plastic hood using a measured flow rate of $1.6 \mathrm{liter} / \mathrm{min}$. Minute by minute measurements were taken over a total measuring time, which included two feeds and two interfeeding periods (i.e., 4-6 h). Measurements were interrupted every $20 \mathrm{~min}$ for $4 \mathrm{~min}$ while the baseline was checked. Feeds were given by gavage via an indwelling orogastric tube so that measurements continued during the feed. For the period when baseline measurements were being recorded, oxygen consumption and carbon dioxide values were estimated by joining adjacent measurement periods to make a continuous estimate.

Behavioural state. The behaviour of the infants was recorded by direct minute by minute observation using the criteria by Prechtl et al. (27) and with a continuous physiograph record of eye movements, respiration, activity, heart rate, and crying.

Anthropometry. Gestational age was assessed from mothers' dates (if firm) or by Dubowitz assessment (12). Body weight was measured to the nearest $5 \mathrm{~g}$ by two independent observers using a nursery beam balance. Head circumference and length were also independently measured using steel tape and a neonatometer, respectively, designed and built at University of Iowa (26). These measurements were carried out every day of the collection periods and on at least 5 days distributed throughout the remaining balance period. Rate of weight gain was estimated by linear regression analysis of body weight on postnatal age. This regression model fitted the data as well as a regression of the logarithm of weight on postnatal age.

Evaluation of overall energy and nitrogen balance. Energy, nitrogen, and fat intakes over the collection periods were calculated from the analyses of the pooled 3-day feed samples and the weights of feed given over this period. Excretion in stool and in urine was calculated from the measured weights and composition of the excreta. From these values, coefficients of energy digestibility and metabolizability, nitrogen digestibility and retention, and fat digestibility were calculated for each collection period for each baby.

For the whole balance period gross energy, nitrogen, and fat intakes of each baby were calculated from the daily weights of feed given throughout the balance period, using the average of the values for the composition of feed determined for each collection period. We assumed that the fall in nitrogen content in human milk was linear over this period (2). The values for digestibility, metabolizability, and retention as determined at each collection period were averaged for each baby; these values were applied to estimates of overall intake to derive values for metabolizable energy intake, nitrogen retained, and fat digested. The three estimates of energy expenditure were combined to give a mean overall value for daily energy expenditure. This was subtracted from the estimate of mean daily metabolizable energy intake to give an estimate of daily energy storage.

Statistical analyses were by unpaired or paired Student's $t$ test where appropriate. Comparison of nutrient intakes, excretion, and coefficients of digestibility, retention, and metabolizability between the feeding groups and collection periods was carried out using analysis of variance and covariance (25). Relationships between energy balance, nitrogen balance, and weight gain were compared by using multiple linear regression analysis (11). 


\section{RESULTS}

Subjects. Nine human milk fed and nineteen formula fed infants were studied (Table 1). Three additional babies, two of whom were formula fed, developed necrotizing enterocolitis and were withdrawn from the study. Fewer human milk fed babies were available for study because at such short gestation many mothers did not express sufficient breast milk to wholly sustain their infants' needs at the time of entry to the study. The human milk fed group did not differ significantly from the formula fed group with respect to birthweight, gestational age, or entry characteristics.

Composition of feed. The compositions of human milk and formula are shown in Table 2. When values for the initial and final collection periods were combined, human milk contained slightly but significantly $(P<0.05)$ more energy than formula $(3.08 \mathrm{~kJ} / \mathrm{g} \mathrm{S}$.D. 0.31 for human milk and $2.91 \mathrm{~kJ} / \mathrm{g} \mathrm{S.D.} 0.11$ for formula). Combined initial and final values for nitrogen in human milk were not significantly different from formula. Measurements of fat content were available in only 42 of 56 samples. In those samples in which estimates were available there were no significant differences in overall fat content between human milk and formula. The energy contents of medications were $24 \mathrm{~kJ} / \mathrm{g}$ for the oil based vitamin $D$ and $E$ preparations, $13 \mathrm{~kJ} / \mathrm{g}$ for Polyvisol, and $7 \mathrm{~kJ} / \mathrm{g}$ for calcium gluconate. On average these medications accounted for $4 \%$ of gross energy intake.

When human milk was compared between collection periods, there were no significant differences in energy or fat content, but nitrogen content was significantly $(P<0.01)$ higher in the initial period. Nitrogen content fell from the initial to the final collection period in each case. The mean rate of fall was $0.04 \mathrm{mg}$ nitrogen/g milk per day. Postnatal age was a significant predictor of nitrogen content $(r=-0.88)$. Nitrogen content at 21 days of age was, on average, $2.41 \mathrm{mg} / \mathrm{g}$.

Mothers who secreted milk of high energy content in the initial period tended to do so also in the final period (Spearman $r=$

Table 1. Characteristics of infants studied, means with range in brackets

\begin{tabular}{lll}
\hline & \multicolumn{1}{c}{$\begin{array}{c}\text { Human } \\
\text { milk fed }\end{array}$} & \multicolumn{1}{c}{ Formula fed } \\
\hline Number & 9 & 19 \\
Birthweight $(\mathrm{kg})$ & $1.32(1.17-1.60)$ & $1.25(0.78-1.70)$ \\
Gestational age $(\mathrm{wk})$ & $30(28-33)$ & $30(27-34)$ \\
On entry to study & & \\
$\quad$ Postnatal age (day) & $12(10-17)$ & $16(5-29)$ \\
$\quad$ Weight $(\mathrm{kg})$ & $1.28(1.11-1.47)$ & $1.25(0.87-1.53)$ \\
Head circumference $(\mathrm{cm})$ & $27.8(27.0-29.0)$ & $27.7(24.5-29.7)$ \\
$\quad$ Length $(\mathrm{cm})$ & $39.7(37.8-41.4)$ & $39.2(34.2-48.9)$ \\
\hline
\end{tabular}

Table 2. Energy, nitrogen and fat in human milk and formula

\begin{tabular}{|c|c|c|c|c|c|c|}
\hline & \multicolumn{3}{|c|}{ Initial 3 days } & \multicolumn{3}{|c|}{ Final 3 days } \\
\hline & $n$ & Mean & S.D. & $n$ & Mean & S.D. \\
\hline \multicolumn{7}{|l|}{ Human milk } \\
\hline Energy $(\mathrm{kJ} / \mathrm{g})$ & 9 & 2.99 & 0.21 & 9 & 3.17 & 0.48 \\
\hline Nitrogen $(\mathrm{mg} / \mathrm{g})$ & 9 & 2.71 & 0.26 & 9 & 2.20 & 0.15 \\
\hline \multirow[t]{3}{*}{ Fat $(g / 100 \mathrm{~g})$} & 6 & 3.26 & 0.32 & 5 & 3.46 & 0.43 \\
\hline & \multicolumn{5}{|c|}{ Initial and final 3 days combined } & \\
\hline & & $n$ & Mean & S.D. & & \\
\hline \multicolumn{7}{|l|}{ Formula } \\
\hline Energy $(\mathrm{kJ} / \mathrm{g})$ & & 38 & 2.9 & & 0.11 & \\
\hline Nitrogen $(\mathrm{mg} / \mathrm{g})$ & & 38 & 2. & & 0.12 & \\
\hline Fat $(\mathrm{g} / 100 \mathrm{~g})$ & & 2 & 3. & & & \\
\hline
\end{tabular}

$0.78 P<0.05$ ). This was not true for nitrogen content (Spearman $r=-0.52 P>0.1$.

Intake and excretion. There was no significant difference between the weight of feed given to the human milk fed infants and that given to the formula fed infants. There were no significant differences in energy intake or excretion between human milk fed and formula fed infants (Table 3 ). In both groups there was a significant increase in mean energy intake between the initial and final collection period $(P<0.05)$. There were no significant differences between human milk fed and formula fed infants or between collection periods in energy excretion in either stool or in urine. There were no significant differences in meta-

Table 3. Daily intakes, stool, urinary losses of energy, nitrogen, and fat during the two collection periods $s^{1}$

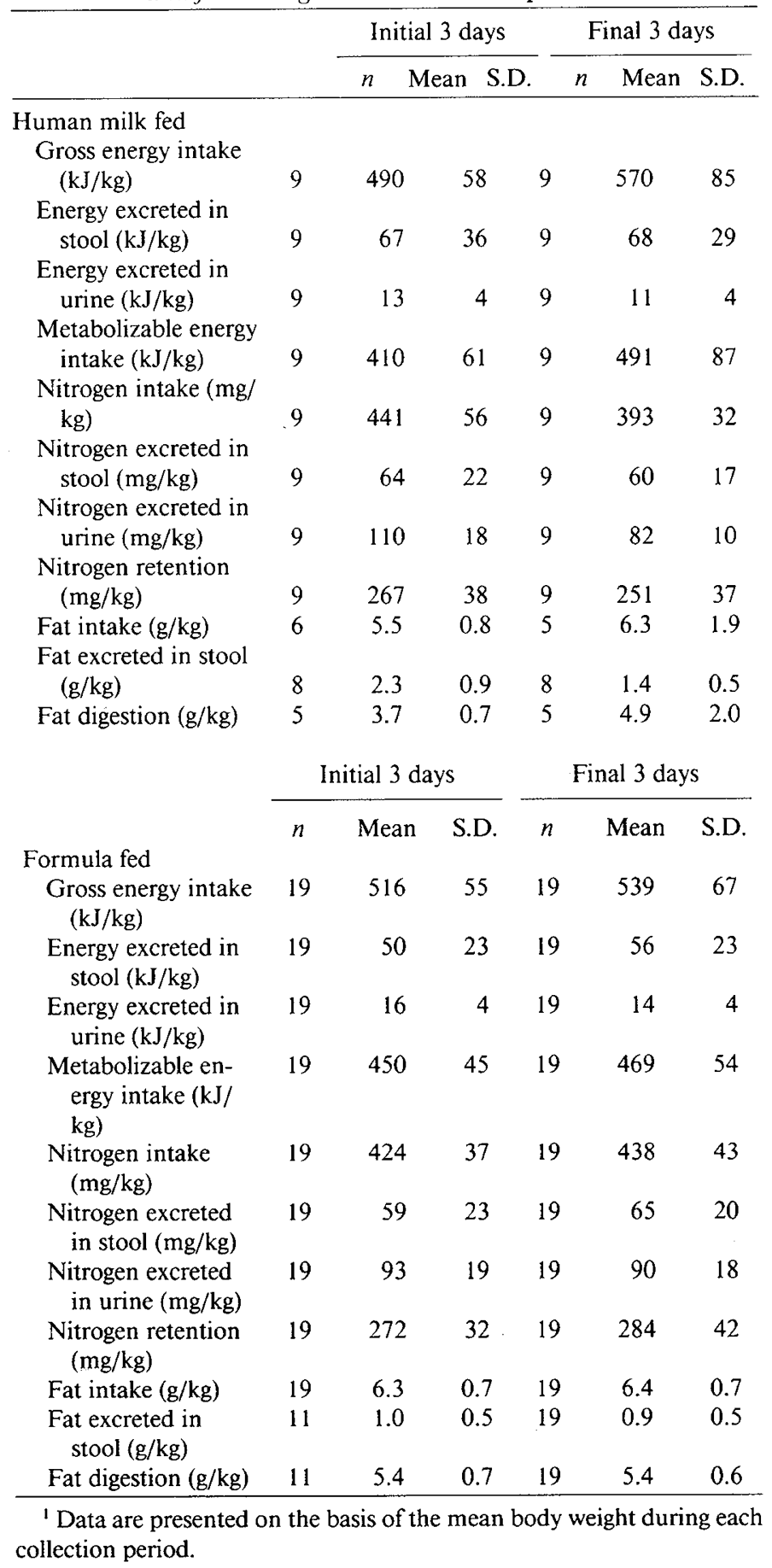


bolizable energy intakes between human milk fed and formula fed infants.

In the human milk fed group, nitrogen intake was higher in the initial collection period and lower in the final collection period than in the formula fed group; the interaction between the time of collection period and the feeding group on nitrogen intake was significant $(P<0.01)$. Urinary nitrogen excretion was higher in the human milk fed group in the initial collection period but lower in the final collection period, which was also reflected in a significant interaction $(P<0.01)$ between collection period and group. There were no significant differences between the dietary groups or collection periods in stool nitrogen excretion or in nitrogen retention.

In the infants for whom samples were available for analysis, fat intake was significantly lower $(P<0.05)$ in the human milk fed group in the initial period only. Fat excretion was significantly higher for the human milk fed than for the formula fed group in both collection periods $(P<0.05)$.

There were no significant differences in energy digestibility, energy metabolizability, nitrogen digestibility, or nitrogen retention between human milk fed and formula fed infants or between collection periods (Table 4). Fat digestibility was significantly $(P$ $<0.05$ ) lower in both collection periods in infants fed with human milk.

Energy expenditure. Measurements of oxygen consumption and carbon dioxide production were completed for eight human milk fed and 19 formula fed infants. For the remaining human milk fed infant, the measurements failed for technical reasons.

The human milk fed group expended significantly less energy than the formula fed group (Table 5). There was no difference between groups in the time spent in different behaviour states. For each group, energy expenditure was higher (by $24 \mathrm{~kJ} /(\mathrm{kg}$. day)) in the final collection period than in the initial collection period. Energy expenditure did not increase in the postprandial period (15-45 min after the feed), but activity and proportion of time spent awake decreased in this period. The relationships between activity, behavioural state, and energy expenditure have been described elsewhere (9).

Energy and nitrogen balances and growth. There were no significant differences between the two dietary groups in weight gain or increase in length or head circumference (Table 5). Metabolizable energy intake, energy storage, and nitrogen retention were very similar in the human milk fed and formula fed infants. In human milk fed infants energy expenditure was $49 \%$ $($ S.D. $=7)$ and energy storage was $51 \%($ S.D. $=7)$ of metaboliz-

Table 4. Gross energy, nitrogen, and fat intakes with coefficients of digestibility, metabolizability, and retention: combined data from both collection periods ${ }^{1}$

\begin{tabular}{|c|c|c|c|c|}
\hline & \multicolumn{2}{|c|}{$\begin{array}{l}\text { Human milk } \\
\qquad(n=9)\end{array}$} & \multicolumn{2}{|c|}{$\begin{array}{l}\text { Formula } \\
(n=19)\end{array}$} \\
\hline & Mean & S.D. & Mean & S.D. \\
\hline \multicolumn{5}{|l|}{ Energy } \\
\hline Gross intake $[\mathrm{kJ} /(\mathrm{kg} \cdot$ day $)]$ & 530 & 68 & 528 & 52 \\
\hline Coefficient of digestibility & 0.87 & 0.05 & 0.90 & 0.03 \\
\hline Coefficient of metabolizability & 0.85 & 0.05 & 0.88 & 0.03 \\
\hline \multicolumn{5}{|l|}{ Nitrogen } \\
\hline Gross intake $[\mathrm{mg} /(\mathrm{kg} \cdot$ day $)]$ & 418 & 36 & 428 & 32 \\
\hline Coefficient of digestibility & 0.85 & 0.03 & 0.86 & 0.04 \\
\hline \multirow[t]{2}{*}{ Coefficient of retention } & 0.62 & 0.03 & 0.64 & 0.05 \\
\hline & \multicolumn{2}{|c|}{$(n=5)$} & \multicolumn{2}{|c|}{$(n=11)$} \\
\hline \multicolumn{5}{|l|}{ Fat } \\
\hline Gross intake $[\mathrm{g} /(\mathrm{kg} \cdot \mathrm{day})]$ & 5.3 & 0.4 & 6.3 & 0.6 \\
\hline Coefficient of digestibility & 0.75 & 0.12 & 0.85 & 0.06 \\
\hline
\end{tabular}

' Data are presented on the basis of body weight at the midpoint of the balance period.
Table 5. Energy balance, nitrogen retention, and growth: values for each dietary group ${ }^{1}$

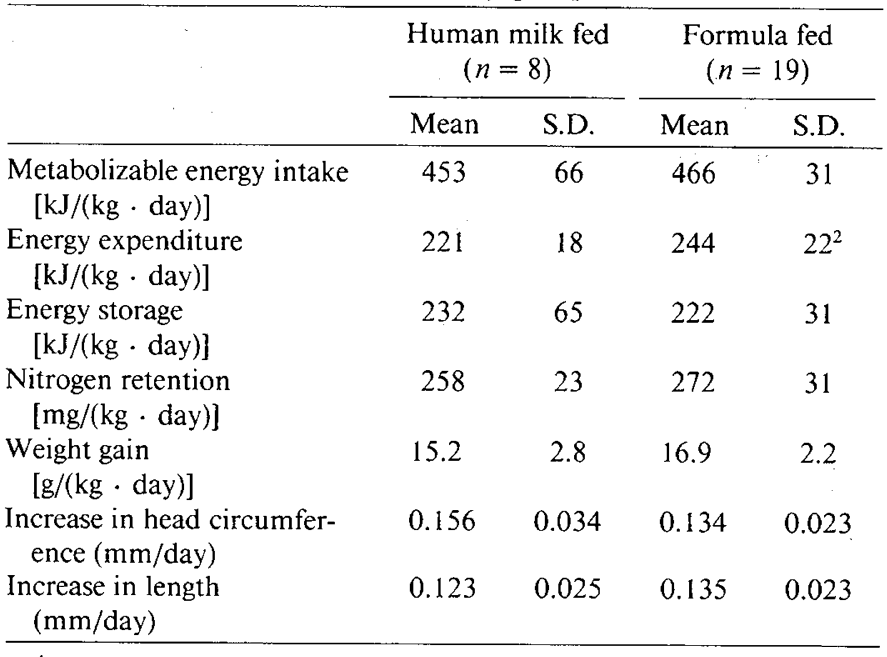

'Only data from infants in whom complete energy balance was available are included. Data are presented on the basis of body weight at midpoint of the balance period.

${ }^{2} P<0.02$.

able energy intake; in formula fed infants energy expenditure was $52 \%($ S.D. $=5)$ and energy storage was $49 \%($ S.D. $=5)$ of metabolizable energy intake. The small difference between the groups in the partition of energy into expenditure and storage was not significant. In human milk fed infants nitrogen retention was $62 \%$ (S.D. $=3$ ) of nitrogen intake whereas in formula fed infants nitrogen retention was $64 \%$ (S.D. $=5$ ) of nitrogen intake. This difference was not significant.

Among human milk fed infants, mean energy storage/g weight gain was $15.3 \mathrm{~kJ} / \mathrm{g}(\mathrm{S} . \mathrm{D} .=2.0)$ and mean nitrogen retention $/ \mathrm{g}$ weight gain was $17.6 \mathrm{mg} / \mathrm{g}(\mathrm{S} . \mathrm{D}$. $=2.6)$. Among formula fed infants, mean energy storage/g weight gain was $13.2 \mathrm{~kJ} / \mathrm{g}$ (S.D. $=1.8$ ) and mean nitrogen retention $/ \mathrm{g}$ weight gain was $16.3 \mathrm{mg} /$ g (S.D. $=2.5)$. Energy stored per gram weight gain was significantly higher $(P<0.02)$ among human milk fed infants; there was no significant difference between the dietary groups in nitrogen stored per gram weight gain. A complete record of observations for each infant is given in Table 6.

\section{DISCUSSION}

In the absence of external work, energy balance is described by the equation (32):

Gross energy intake

$=$ Energy excreted + Energy expended + Energy stored

Digested energy is that which remains from gross energy intake after stool energy excretion has been taken into account. Metabolizable energy is energy available for expenditure or storage, and is the energy remaining from the gross energy intake after subtracting energy excreted in stool and urine.

Human milk differed from the formula in that the gross energy content was slightly higher. The value determined by bomb calorimetry $(3.08 \mathrm{~kJ} / \mathrm{g})$ is similar to that estimated from fat, protein, and nitrogen content $(2.97 \mathrm{~kJ} / \mathrm{g})$ at similar gestational and postnatal age by others (1). Both these values are substantially higher than estimates of energy content of term pooled human milk at similar postnatal age $(2.47 \mathrm{~kJ} / \mathrm{g})(1)$.

The declared energy content of the formula was $68 \mathrm{kcal} / 100$ $\mathrm{ml}$ which, with a specific gravity of 1.03 , is equivalent to 2.76 $\mathrm{kJ} / \mathrm{g}$. This value is $5 \%$ lower than our direct estimate of $2.91 \mathrm{~kJ} /$ $\mathrm{g}$. The discrepancy is due to the manufacturer's use of Atwater's 
HUMAN MILK VS FORMULA

Table 6. Initial weight on entry to the study, daily weight gain, energy balance, and nitrogen retention: values for individual subjects

\begin{tabular}{|c|c|c|c|c|c|c|}
\hline No. & $\begin{array}{c}\text { Initial } \\
\text { weight } \\
(\mathrm{kg})\end{array}$ & $\begin{array}{l}\text { Weight } \\
\text { gain } \\
\text { (g/day) }\end{array}$ & $\begin{array}{c}\text { Metabolizable } \\
\text { energy intake } \\
(\mathrm{kJ} / \text { day })\end{array}$ & $\begin{array}{c}\text { Energy } \\
\text { expended } \\
(\mathrm{kJ} / \text { day })\end{array}$ & $\begin{array}{c}\text { Energy } \\
\text { stored } \\
\text { (kJ/day) }\end{array}$ & $\begin{array}{c}\text { Nitrogen } \\
\text { retained } \\
\text { (mg/day) }\end{array}$ \\
\hline \multicolumn{7}{|c|}{ Human milk fed } \\
\hline 1 & 1.48 & 24.0 & 709 & 341 & 368 & 430 \\
\hline 2 & 1.06 & 24.4 & 559 & 236 & 323 & 335 \\
\hline 3 & 1.39 & 29.5 & 938 & 362 & 576 & 461 \\
\hline 4 & 1.32 & 21.1 & 669 & 330 & 339 & 415 \\
\hline 5 & 1.35 & 17.1 & 588 & 334 & 254 & 317 \\
\hline 6 & 1.27 & 18.8 & 535 & 289 & 246 & 330 \\
\hline 7 & 1.14 & 14.4 & 514 & 307 & 207 & 317 \\
\hline 8 & 1.23 & 23.5 & 707 & 327 & 380 & 362 \\
\hline Mean & 1.28 & 21.6 & 652 & 316 & 337 & 371 \\
\hline S.D. & 0.13 & 4.8 & 138 & 39 & 115 & 57 \\
\hline \multicolumn{7}{|l|}{ Formula fed } \\
\hline 1 & 1.14 & 21.5 & 600 & 282 & 318 & 359 \\
\hline 2 & 1.53 & 28.9 & 790 & 430 & 360 & 468 \\
\hline 3 & 1.66 & 32.4 & 835 & 420 & 415 & 384 \\
\hline 4 & 1.35 & 20.6 & 756 & 416 & 340 & 468 \\
\hline 5 & 1.29 & 25.3 & 679 & 286 & 393 & 488 \\
\hline 6 & 1.18 & 20.5 & 605 & 375 & 230 & 344 \\
\hline 7 & 0.95 & 23.6 & 606 & 287 & 319 & 351 \\
\hline 8 & 1.13 & 20.4 & 587 & 310 & 277 & 361 \\
\hline 9 & 1.12 & 20.9 & 574 & 295 & 279 & 291 \\
\hline 10 & 1.16 & 22.3 & 635 & 315 & 320 & 393 \\
\hline 11 & 1.29 & 30.6 & 782 & 380 & 402 & 404 \\
\hline 12 & 1.22 & 31.2 & 695 & 400 & 295 & 418 \\
\hline 13 & 1.47 & 23.7 & 745 & 378 & 367 & 371 \\
\hline 14 & 1.31 & 23.6 & 634 & 348 & 286 & 411 \\
\hline 15 & 1.40 & 26.0 & 689 & 378 & 311 & 391 \\
\hline 16 & 1.37 & 27.5 & 683 & 380 & 303 & 430 \\
\hline 17 & 1.21 & 20.1 & 582 & 352 & 230 & 360 \\
\hline 18 & 0.87 & 13.3 & 422 & 213 & 209 & 242 \\
\hline 19 & 1.13 & 19.0 & 552 & 295 & 257 & 321 \\
\hline Mean & 1.25 & 23.8 & 655 & 344 & 311 & 382 \\
\hline S.D. & 0.19 & 4.8 & 100 & 59 & 59 & 61 \\
\hline
\end{tabular}

fuel values (22) (4 kcal/g of protein or of carbohydrate and 9 $\mathrm{kcal} / \mathrm{g}$ of fat) in calculating energy content. These fuel values are, in fact, metabolizable energy values derived from young adults. The gross energy values (heats of combustion) determined by Atwater were $5.65 \mathrm{kcals}(23.6 \mathrm{~kJ}) / \mathrm{g}$ of protein, $3.95 \mathrm{kcals}(16.5$ $\mathrm{kJ}) / \mathrm{g}$ of carbohydrate and $9.25 \mathrm{kcals}(38.7 \mathrm{~kJ}) / \mathrm{g}$ of fat. Applying these values to the label declarations of the formula predicts a gross energy of $2.87 \mathrm{~kJ} / \mathrm{g}$, which is not significantly different from our direct measurement. Atwater's fuel values cannot be applied to infants because their excretory losses are higher than those of adults. One is left with the choice of expressing the energy content of the formula as $2.91 \mathrm{~kJ}$ gross energy content/g or, given that in the formula fed group $88 \%$ of gross energy intake was metabolizable, as $2.56 \mathrm{~kJ}$ metabolizable energy/g. For all babies combined metabolizable energy intake was $86 \%$ (S.D. $=4$ ) of gross energy intake and nitrogen retention was $64 \%$ (S.D. $=5$ ) of nitrogen intake. These values are close to those recently indirectly estimated for infants of similar gestation (4).

Human milk and formula did not differ in average nitrogen content when both periods were combined. Nitrogen content in human milk fell with postnatal age at a rate $(0.04 \mathrm{mg} \mathrm{N} / \mathrm{g}$ per day) very similar to that described by Atkinson et al (2). Despite higher nitrogen levels in the first $2 \mathrm{wk}$, average nitrogen content fell below that of the formula by 3 wk of postnatal age.

The only difference demonstrated in the digestion or retention of the nutrients of human milk and formula was that the fat in formula was more digestible. This observation may be partly explained by the large percentage of fat present as laurate (C12:0) in the formula ( $26 \%$ versus $4 \%$ in human milk) $(16,31)$. This fatty acid is intermediate between the long chain and medium chain triglycerides and may, like the medium chain triglycerides (33), be more readily absorbed from the gastrointestinal tract than long chain triglycerides. Furthermore, as medium chain triglycerides are more readily oxidized than are long chain triglycerides (5), this difference in fatty acid composition may also contribute to the higher energy expenditure seen in the formula fed infants.

The effect of hydrogen on the diaferometer has been described (7) but has not been taken into account by more recent workers $(8,20)$. The low birthweight infant produces substantial quantities of breath hydrogen, which arise from fermentation of lactose in the colon (23). It can be calculated that the very high energy equivalents for oxygen consumption used by Brooke et al. (8) for some of their subjects correspond to very high respiratory quotients such as we measured before making the correction for hydrogen excretion. The food quotients calculated in our study are indirect estimates of respiratory quotients. Based on these estimates, more fat was stored than could be accounted for by digested fat in 11 infants; in these cases one would expect respiratory quotients to be greater than one (24).

The relationship between the respiratory quotient and the energy equivalent of carbon dioxide has not been described for 
respiratory quotients exceeding one; we have chosen not to extrapolate the relationship past unity for respiratory quotients. The energy equivalents thus derived for carbon dioxide ranged between 21.12 and $22.18 \mathrm{~kJ} /$ liter.

The estimate of daily energy expenditure is based on measurements taken over two interfeeding intervals: there is some, albeit limited, experimental justification for this extrapolation (10). The confidence with which this prediction can be made would bear further experimental examination. Losses of feed and excreta may combine to cause overestimation of amounts of retained or stored nutrients: we have attempted to minimize this problem, which is common to all balance studies. Currently available techniques for estimating body composition are not accurate enough for use in low birthweight infants.

Prediction of weight gain. Stepwise multiple linear regression analysis (11) was performed to determine the predictors of weight gain within each dietary group. The independent variables tested were metabolizable energy intake, energy expenditure, nitrogen retention, initial weight, and postnatal age. In human milk fed infants, weight gain was predicted (Table 7) from initial weight, metabolizable energy intake, and energy expenditure $\left(r^{2}=0.96\right)$. For the formula group, weight gain was best predicted from metabolizable energy intake alone $\left(r^{2}=0.69\right)$; the addition of energy expenditure did not significantly improve the prediction of weight gain. Nitrogen retention did not make a significant contribution to the prediction of weight gain for either group.

Composition of weight gain. Energy intake and nitrogen intakes were similar in the two dietary groups; therefore, it was of interest to compare the two groups with respect to the composition of weight gain. Prediction equations for energy storage and nitrogen retention were derived for each group using stepwise multiple linear regression. The possible determinants examined were the babies' initial weight, rate of weight gain, postnatal age, and, where appropriate, rate of energy storage and nitrogen retention. The prediction equations are given in Table 7 . Energy storage was predicted by weight gain alone for both human milk fed infants $\left(r^{2}=0.84\right)$ and for formula fed infants $\left(r^{2}=0.51\right)$. In both groups of infants nitrogen retention was predicted from energy storage alone. These equations were then used to estimate the composition of weight gain for each dietary group, assuming (1) gross energy values of $38.7 \mathrm{~kJ} / \mathrm{g}$ for fat and $23.6 \mathrm{~kJ} / \mathrm{g}$ for protein; (2) that $16 \%$ of protein is nitrogen; and (3) that carbohydrate storage is negligible. For human milk fed infants, the composition of weight gain was calculated as $10.7 \%$ protein and $33.8 \%$ fat; for formula fed infants it was $10.1 \%$ protein and $27.7 \%$ fat.

The prediction equations were used to explore the effect of rate of weight gain on the composition of weight gain. We repeated the calculations setting weight gain at 1 S.D. below and 1 S.D. above the mean rate of weight gain within each dietary group. The rate of fat accretion was greater in the faster growing infants in both dietary groups, but in the human milk fed infants

Table 7. Predictions of weight gain, energy storage, and nitrogen retention ${ }^{1}$

\begin{tabular}{ll}
\hline & $r^{2}$ \\
\hline Human milk fed $(n=8)$ & \\
Wgn $=14.87+11.03 \mathrm{Wt}+0.045 \mathrm{MEI}-0.117 \mathrm{EEX}$ & 0.96 \\
$\mathrm{ES}=-145.7+22.33 \mathrm{Wgn}$ & 0.84 \\
NRet $=229.3+0.421 \mathrm{ES}$ & 0.68 \\
Formula fed $(n=19)$ & \\
Wgn $=-2.88+0.041 \mathrm{MEI}$ & 0.69 \\
$\mathrm{ES}=99.43+8.91 \mathrm{Wgn}$ & 0.51 \\
NRet $=175.7+0.663 \mathrm{ES}$ & 0.37 \\
\hline
\end{tabular}

${ }^{1}$ Abbreviations: weight gain, $\mathrm{g} /$ day (Wgn); initial weight, $\mathrm{kg}(\mathrm{Wt})$; metabolizable energy intake, $\mathrm{kJ} /$ day (MEI); energy expenditure, $\mathrm{kJ} /$ day (EEX); energy storage, $\mathrm{kJ} / \mathrm{day}(\mathrm{ES})$; and nitrogen retention, $\mathrm{mg} / \mathrm{day}$ (NRet).
HUMAN MILK FED Initial Weight $1.28 \mathrm{~kg}$

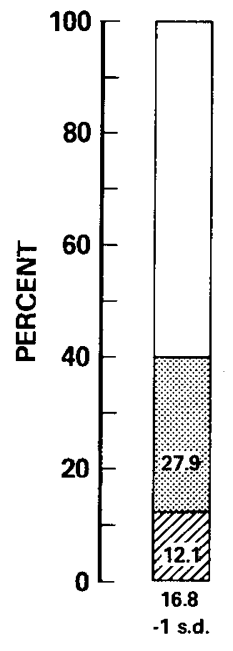

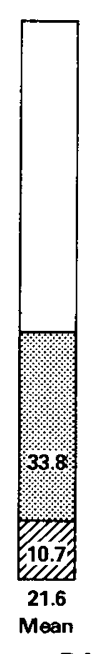

FORMULA FED

Initial Weight $1.25 \mathrm{~kg}$

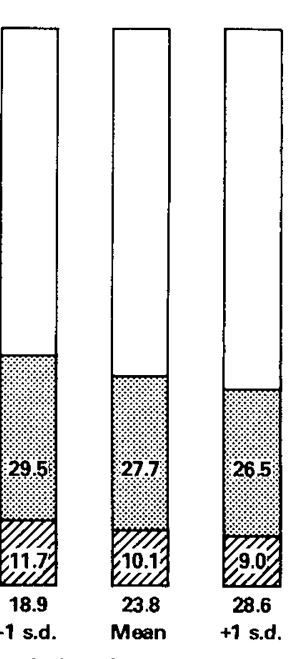

Fig. 2. Percentage composition of weight gain in low birthweight infants fed either mother's expressed breast milk or formula (Similac 20 $\mathrm{kcal} / \mathrm{oz}$ ). In each dietary group, the three bars describe the \% composition of weight gain of babies who gain at the mean rate for that dietary group, 1 S.D. below the mean rate or 1 S.D. above the mean rate. The daily rates of weight gain ( $g /$ day) are given by the numbers at the bottoms of the columns. The numbers within the bars indicate the $\%$ of weight gained as protein and as fat

the increase in rate of fat accretion was substantially greater than in the formula fed infants. In human milk fed infants, \% of weight gained as fat increased with increasing rates of weight gain; in formula fed infants it fell (Fig. 2). In both groups $\%$ of weight gained as protein was lower with increasing rates of weight gain. Infants fed human milk who grew at 1 S.D. below the mean rate stored $13.7 \mathrm{~kJ}$ energy/g weight gain; for those growing at 1 S.D. above the mean rate this figure rose to $16.8 \mathrm{~kJ} / \mathrm{g}$. In contrast, formula fed infants growing at 1 S.D. below mean weight gain stored $14.1 \mathrm{~kJ}$ energy/g weight gain; this fell to $12.4 \mathrm{~kJ} / \mathrm{g}$ among formula fed infants growing at 1 S.D. above mean weight gain. The composition of weight gain was sensitive not only to the nature of the diet but also to the rate of weight gain within each dietary group.

Comparison with previous studies. There are no previous published studies with which to compare our balance data on very low birthweight infants fed their mother's expressed breast milk. Two previous studies $(8,29)$ have reported the energy balance of such infants fed formula, and one of these (29) has also reported the nitrogen balance and composition of weight gain.

Brooke et al. (8) studied the energy balance of 15 healthy, growing low birthweight infants fed V formula (Cow and Gate). Their infants were somewhat larger than our formula fed infants at birth (mean birthweight $1.58 \mathrm{~kg}$ ) and they were fed a much higher gross energy intake $[757 \mathrm{~kJ} /(\mathrm{kg}$. day) versus $528 \mathrm{~kJ} /(\mathrm{kg}$. day)]. In our study metabolizable energy intake averaged $88 \%$ $($ S.D. $=3 \%)$ of gross energy intake for formula fed infants whereas in the study of Brooke et al. metabolizable energy intake was a lower and more variable fraction of gross energy intake $(76.2 \%$, S.D. $=8.3 \%)$. Energy expenditure was considerably higher [369 kJ/(kg. day) versus $244 \mathrm{~kJ} /(\mathrm{kg}$. day) in our formula fed infants]. Despite the substantially higher gross energy intake of the infants studied by Brooke et al., energy storage was very similar $[230 \mathrm{~kJ} /(\mathrm{kg}$. day $)]$ to that which we found $[222 \mathrm{~kJ} / \mathrm{kg}$. day)]. Because their infants gained weight at a slower rate than ours [13.7 versus $16.9 \mathrm{~g} /(\mathrm{kg}$. day)], energy stored $/ \mathrm{g}$ weight gain was higher in their infants (16.8 versus $13.2 \mathrm{~kJ} / \mathrm{g}$ ). 
Reichman et al. (29) studied 13 formula fed infants (fed SMA, Wyeth) who were almost identical to our 19 formula fed infants in body weight at entry to the study although they were slightly older. Again, these babies received a higher gross energy intake than ours [622 versus $528 \mathrm{~kJ} /(\mathrm{kg}$. day)]. Because the proportions of gross energy intake that were excreted and expended were very similar to our findings, the babies studied by Reichman et al. had a higher energy storage than ours $[284$ versus $222 \mathrm{~kJ} /(\mathrm{kg}$. day)]. Nitrogen intake was higher $[510$ versus $431 \mathrm{mg} /(\mathrm{kg}$. day)] but nitrogen retention was only marginally higher; thus, retention averaged only $60 \%$ of intake versus $64 \%$ in our babies. Gains in weight, length and head circumference were almost identical in the two studies. Energy storage per gram weight gain was higher in their infants (16.9 versus $13.2 \mathrm{~kJ} / \mathrm{g}$ ) as was nitrogen retention/ $\mathrm{g}$ weight gain (18.3 versus $16.3 \mathrm{mg} / \mathrm{g}$ ). Correspondingly, \% weight gain as protein, and as fat, were higher than in our infants (for protein, $11.4 \%$ versus $10.1 \%$; for fat, $32.0 \%$ versus $27.7 \%$ ).

All three studies agree that formula fed low birthweight babies have a much higher fat accretion rate (and energy cost of weight gain) then has been calculated for fetal growth in utero at the equivalent body weight or post-conceptional age $(36,37,38)$. This is even more true of the low birthweight baby fed mother's expressed breast milk who is rapidly gaining weight. We calculate that such an infant has a fat accretion rate close to that described for the first four months of extrauterine growth of the "male reference infant" born at term (14).

Weight gain in low birthweight infants fed their own mother's expressed breast milk consists of greater quantities of fat than does the weight gain of infants fed formula. Furthermore, the composition of weight gain depends on the rate of weight gain. Low birthweight infants fed human milk who gain weight rapidly do so by increasing the proportion of weight gained as fat; formula fed infants who gain weight rapidly do so by increasing the proportion of weight gained as water and mineral.

When growing low birthweight infants fed on their own mother's expressed milk were compared with similar infants fed with formula (Similac $20 \mathrm{kcal} /$ ounce): (I) there were no differences in the proportions of energy or nitrogen intakes lost in stool and urine; (2) infants fed with human milk expended less energy than those fed with formula; (3) although metabolizable energy intakes were similar, infants fed with human milk stored significantly greater quantities of energy per gram weight gain than those fed with formula; and (4) energy storage was a better predictor of weight gain than was nitrogen retention.

\section{APPENDIX}

Derivation of food quotient. The diaferometer measurements of oxygen consumption were affected by breath hydrogen. This was brought to our attention towards the latter part of the study. We were therefore obliged to derive a respiratory quotient from a knowledge of daily carbon dioxide production rate $\left(\dot{\mathrm{VCO}}_{2}\right)$, daily nitrogen retention (N RETAINED), daily nitrogen urinary excretion rate (N OXIDIZED), and daily metabolizable energy intake (Fig. 3).
As the energy equivalent of $\mathrm{CO}_{2}\left(\mathrm{~kJ}\right.$ expended per liter $\mathrm{CO}_{2}$ consumed) is the variable estimated, it becomes necessary to arbitrarily choose an energy equivalent to start the reiterative cycle. In this computation the value equivalent to a non-protein respiratory quotient of one is taken $(21.12 \mathrm{~kJ} /$ liter $)$. The rate of oxidation of protein is calculated from the urinary nitrogen excretion rate, and the $\mathrm{VCO}_{2}$ value is converted to a nitrogenfree value $\left(\mathrm{N}-\mathrm{FREE} \mathrm{VCO}_{2}\right.$ ) by subtracting the carbon dioxide generated by protein oxidation. The following formula is used to establish the quantity of carbon dioxide generated from protein oxidation:

$$
1 \mathrm{~g} \text { urinary nitrogen } \equiv 4.76 \text { liter } \dot{\mathrm{VCO}}_{2}
$$

This value is substracted from $\mathrm{VCO}_{2}$ (liter/day). The resulting $\mathrm{N}$-FREE $\mathrm{VCO}_{2}$ is multiplied by the energy equivalent of $\mathrm{CO}_{2}$ $(21.12 \mathrm{~kJ} /$ liter $)$. To this value is added the energy expended in nitrogen oxidation obtained from the equation:

\section{$1 \mathrm{~g}$ urinary nitrogen $\equiv 111 \mathrm{~kJ}$ energy expended}

The total energy expenditure so obtained is subtracted from the metabolizable energy intake. The difference is energy stored, and it is assumed that this is stored entirely as fat and protein. To subtract the energy value of protein stored, assuming a value of $6.25 \mathrm{~g}$ protein/g nitrogen we use the equation:

\section{$1 \mathrm{~g}$ nitrogen retained $\equiv 6.25 \times 23.64 \mathrm{~kJ}$ stored energy}

Therefore, energy stored as nitrogen $\equiv 148 \mathrm{~kJ} / \mathrm{g} \mathrm{N}$. This can be subtracted from the total energy stored to obtain the energy stored as fat. As we know the amount of fat digested, we can subtract fat stored from fat digested to give us the net amount of fat oxidized. By converting this value to $\mathrm{kJ} /$ day expended from fat (using the constant $38.7 \mathrm{~kJ} / \mathrm{g}$ fat) this is related to the respiratory quotient (RQ) and to the energy equivalent of $\mathrm{CO}_{2}$. Where $f$ is the fraction of non-protein energy expenditure derived from the oxidation of fat:

$$
\mathrm{RQ}=1-0.3 \mathrm{f}
$$

Energy equivalent of $\mathrm{CO}_{2}=21.12+6.878 \mathrm{f}$

At $R Q=1(0 \%$ energy from fat oxidation $)$ the energy equivalent of $\mathrm{CO}_{2}$ is $21.12 \mathrm{~kJ} /$ liter and at $\mathrm{RQ}=0.7(100 \%$ energy from fat oxidation) the energy equivalent is $28.00 \mathrm{~kJ} /$ liter. Now the newly derived energy equivalent can be compared to the original starting equivalent which was given as $21.12 \mathrm{~kJ} / \mathrm{liter}$. If the new equivalent differs from the old, it replaces it and the whole sequence of calculations starts again, reiterating until the two consecutive estimates of the energy equivalent match to four decimal places. When this condition is fulfilled, the energy equivalent is used to calculate energy expenditure, energy storage, and RQ. Values for the energy equivalent of $\mathrm{CO}_{2}$ for RQs in excess of 1 have not been extrapolated: in the instances in which the RQ exceeded 1 (i.e., where net fat storage exceeded fat absorption) we assumed a value for the energy equivalent of $\mathrm{CO}_{2}$

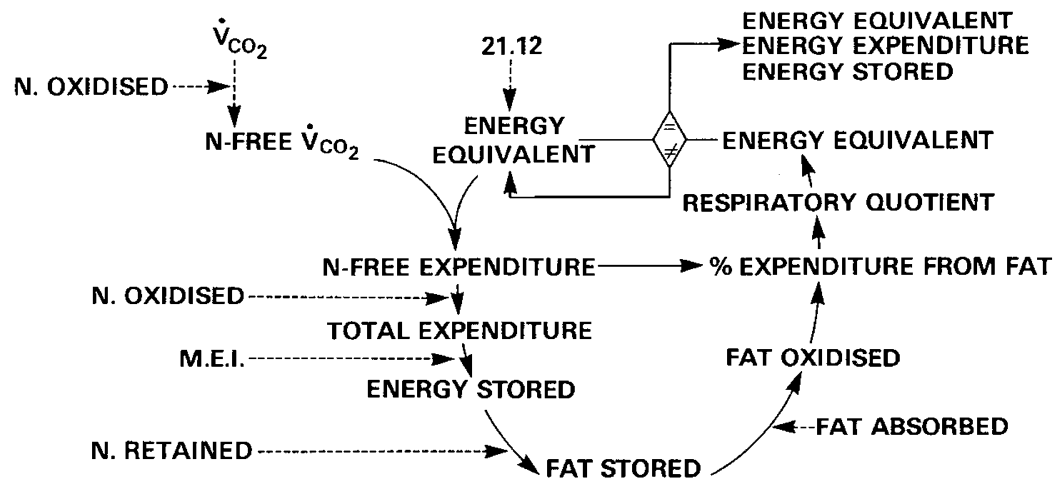

Fig. 3. Derivation of energy equivalent of carbon dioxide. The variables are entered in the order indicated. 
of $21.12 \mathrm{~kJ} /$ liter. All conversion constants used were taken from Brody (7) and the heats of combustion of Atwater (22).

Balance techniques may overestimate nitrogen retention or fat digestion. These errors have different effects at various points in the calculation of the energy equivalent. The overall effect of a $10 \%$ overestimate of nitrogen retention is an overestimate of energy expenditure of $0.5 \%$ : that of a $10 \%$ overestimate of fat digestion is an overestimate of energy expenditure of $0.07 \%$.

Example. An infant who has a $\mathrm{VCO}_{2}$ of $7.25 \mathrm{ml} / \mathrm{min}(10.44$ liter/day) has daily values for metabolizable energy intake of 466 $\mathrm{kJ}$, nitrogen retention of $276 \mathrm{mg}$, urine nitrogen excretion of 90 $\mathrm{mg}$, and fat digestion of $5.4 \mathrm{~g}$.

The reiterative programme gives an energy equivalent of carbon dioxide of $21.35 \mathrm{~kJ} /$ liter equivalent to a respiratory quotient of 0.99 . Energy expenditure is $224 \mathrm{~kJ} /$ day and energy storage is $242 \mathrm{~kJ} /$ day. Of the total energy expenditure $4.5 \%$ was derived from protein oxidation: of the non-protein energy expended $3.3 \%$ was derived from fat oxidation.

\section{REFERENCES AND NOTES}

1. Anderson, G. H., Atkinson, S. A., and Bryan, M. H.: Energy and macronutrient content of human milk during early lactation from mothers giving birth prematurely and at term. Am. J. Clin Nutr., 34: 258 (1981).

2. Atkinson, S. A., Bryan M. H., and Anderson, G. H.: Human milk: difference in nitrogen concentration in milk from mothers of term and premature infants. J. Pediatr., 93: 67 (1978).

3. Atkinson, S. A., Radde, I. C., Chance, G. W., Bryan M. H., and Anderson, G. H.: Macromineral content of milk obtained during early lactation from mothers of premature infants. Early Hum. Dev., 4: 5 (1980).

4. Atkinson, S. A., Bryan, M. H., and Anderson, G. H.: Human milk feeding in premature infants: protein, fat and carbohydrate balances in the first two weeks of life. J. Pediatr., 99:617 (1981).

5. Baba, N., Bracco, E. F., and Hashim, S. A.: Enhanced thermogenesis and diminished deposition of fat in response to overfeeding with diet containing medium chain triglyceride. Am. J. Clin. Nutr., 35: 678 (1982).

6. Bligh, E. G. and Dyer, W. S.: A rapid method of total lipid extraction and purification. Can. J. Biochem. Physiol., 37: 911 (1959).

7. Brody, S.: Methods in animal calorimetry. In: Bioenergetics and Growth. p. 307 (Reinhold Publishing Corporation, Waverly Press, Baltimore, 1945).

8. Brooke, O. G.. Alvear, J., and Arnold, M.: Energy retention, energy expenditure, and growth in healthy immature infants. Pediatr. Res., 13: 215 (1979).

9. Campbell, D., Shannon, S., Whyte, R. K., Vlainic, C., and Sinclair, J. C.: Energy balance and behaviour in the low-birth-weight infant. Society for Research in Child Development Biennial Meeting. p. 21 (Boston, MA, 1981).

10. Chessex, P., Reichman, B. L., Verellen, G. J. E., Putet, G., Smith, J. M., Heim, T., and Swyer, P. R. Influence of postnatal age, energy intake, and weight gain on energy metabolism in the very low birthweight infant. Pediatrics, 99 : 761 (1981).

11. Dixon, W. J. and Brown, M. B.: Biomedical Computer Programs P Series. p. 653 (University of California Press, Berkley, Los Angeles, 1979).

12. Dubowitz, L. M. S., Dubowitz, V., and Goldberg, C.: Clinical assessment of gestational age in the newborn infant. J. Pediatr., 77: 1 (1970).

13. Flatt, J. P.: The biochemistry of energy expenditure. In: G. A. Bray (Ed.): Recent Advances in Obesity Research. Vol. 2. p. 211 (Newman Publishing Ltd., Westport, 1978).

14. Fomon, S. J.: Body composition of the male reference infant during the first year of life. Pediatrics, 40: 863 (1967).

15. Fomon, S. J., Ziegler, E. E., and Vazquez, H. D.: Human milk and the small premature infant. Am. J. Dis. Child., 131: 463 (1977).

16. Gibson, R. A. and Kneebone, G. M.: Fatty acid composition of human colostrum and mature breast milk. Am. J. Clin. Nutr., 34: 252 (1981).

17. Gross, S. J., David, R. J.. Bauman, L., and Tomarelli, R. M.: Nutritional composition of milk produced by mothers delivering preterm. J. Pediatr.,
96: $641(1980)$.

18. Hepner, R. and Lubchenco, L. O.: A method for continuous stool and urine collection in young infants. Pediatrics, 26: 828 (1960).

19. Horwitz, W. (Ed.): Official methods of analysis of the Association of Official Analytical Chemists, 12th ed. Washington, D.C. Association of Official Analytical Chemists, No. 248 (1975).

20. LeBlanc, M. H.: Relative efficacy of an incubator and an open warmer in producing thermoneutrality for the small premature infant. Pediatrics, 69 : 439 (1982).

21. Malloy, M. H. and Gaull, G. E.: Enteral protein and amino acid nutrition in preterm infants. Semin. Perinatol., 3: 4 (1979).

22. Merrill, A. L. and Watt. B. K.: Energy value of foods: basis and derivation. Agriculture Handbook No. 74, United States Department of Agriculture (1973).

23. MacLean, W. C. and Fink, B. B.: Lactose malabsorption by premature infants: magnitude and clinical significance. J. Pediatr., 97: 383 (1980).

24. Mount, L. E.: In: The Climatic Physiology of the Pig. p. 103 (Edward Arnold, London, 1968).

25. Nie, N. H., Hull, C. H., Jenkins, J. G., Steinbrenner, K., and Bent. D.: Statistical Package for the Social Sciences. 2nd Edition. p. 13 (McGraw-Hill, New York 1975).

26. Owen, G. M.: The assessment and recording of measurements of growth in children: report of a small conference. Pediatrics, 51: 461 (1973).

27. Prechtl, H. F. R., Faigel, J. W., Weinmann, H. M., and Bakker, H. M. Postures, mobility and respiration of low-risk preterm infants. Dev. Med. Child. Neurol., 21: 3 (1979).

28. Reichman, B. L., Chessex. P., Putet, G., Verellen, G. J. E., Smith, J. M., Heim, T., and Swyer, P. R.: Partition of energy metabolism and energy cost of growth in the very low-birth-weight infant. Pediatrics, 69:446 (1982)

29. Reichman, B. L., Chessex, P., Putet, G., Verellen, G., Smith, J. M., Heim, T. and Swyer, P. R.: Diet, fat accretion and growth in premature infants. N Engl. J. Med., 305: 1495 (1982).

30. Shenai, J. P.: Balance studies in newborn infants. J. Pediatr., 93: 533 (1978).

31. Similac/Similac with Iron. Product Monograph. (Ross Laboratories, Columbus, $\mathrm{OH}$ 1978).

32. Sinclair, J. C.: Energy balance of the newborn. In: Temperature Regulation and Energy Metabolism in the Newborn. J. C. Sinclair (Ed): Chap. 7. (Grune and Stratton. New York, 1978).

33. Tantbedhyangkul, P. and Hashim, S. A.: Clinical and physiological aspects of medium chain triglycerides: alleviation of steatorrhea in premature infants. Bull. N.Y. Acad. Med., 47: 17 (1971).

34. Ten Hoor, F., Rispens, $P$. van de Wall, E, and Zijlstra, W. G. Determination of oxygen uptake and carbon dioxide production in animals and man using a diaferometer calibrated with expired gas. Koninkl Nederl Akademie van Wetten Schappen (Amsterdam). p. 429 (Proceedings Series C, 77, No. 5 , 1974).

35. Van de Kamer, J. H., ten Bokkel Huinink, H., and Weyers, H. A.: Rapid method for the determination of fat in feces. J. Biol. Chem., 177: 347 (1949).

36. Whyte, R. K., Sinclair, J. C., Bayley, H. S., Campbell, D., and Singer, J.: On the energy cost of growth of premature infants. Acta Pediatr. Acad. Sci. (Hungary), 23: 85 (1982).

37. Widdowson, E. M.: Importance of nutrition in development, with special reference to feeding the low-birth-weight infant. In: Meeting Nutritional Goals for Low Birthweight Infants: Proceedings of the Second Ross Clinical Research Conference. pp. 4-11 (Ross Laboratories, Columbus. OH 1982).

38. Ziegler, E. E., O'Donnell, A. M., Nelson, J. E., and Fomon, S. J.: Body composition of the reference fetus. Growth. 40: 329 (1976).

39. We acknowledge with thanks the help of Dr. Joel Singer, Department of Clinical Epidemiology and Biostatistics, who advised us and conducted the statistical analysis.

40. Requests for reprints should be addressed to: Dr. R. K. Whyte, McMaster University Medical Centre, 1200 Main Street West, Room 3V42, Hamilton, Ontario, Canada.

41. This research was supported by a Fellowship from Medical Research Council of Canada Supported by grants from the National Institute of Child Health and Human Development (HD 12469) and Ross Laboratories, Columbus. Ohio.

42. Received for publication August 13, 1982

43. Accepted for publication March 15, 1983. 